\title{
A whole-systems design approach to city living
}

\author{
Sharon Ferguson ${ }^{\text {a* }}$ \\ City of Anchorage, Alaska \\ Jillian Ferguson ${ }^{\mathrm{b}}$ \\ City of Chicopee, Massachusetts
}

\section{Review of The Permaculture City: Regenerative Design for Urban, Suburban, and Town Resilience, by Toby Hemenway. (2015). Published by Chelsea Green Publishing; 288 pages; available as eBook and paperback. Publisher's website: http://www.chelseagreen.com/the-permaculture-city}

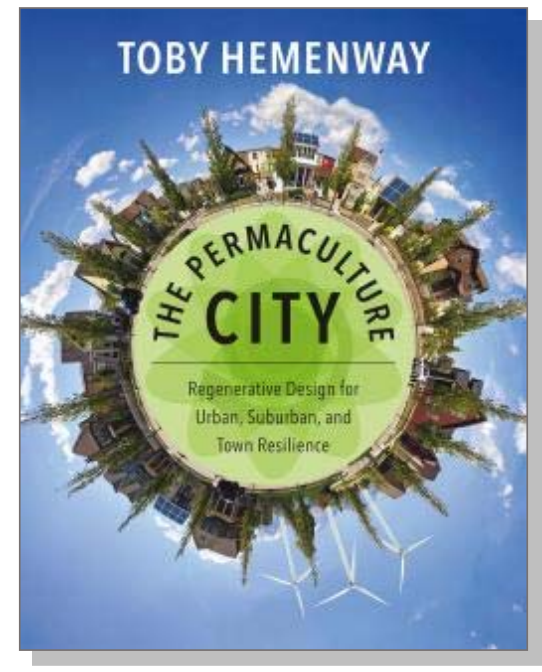

Submitted December 4, 2015 / Published online April 8, 2016

Citation: Ferguson, S., \& Ferguson, J. (2016). A whole-systems design approach to city living [Book review]. Journal of Agriculture, Food Systems, and Community Development, 6(2), 315-316. http://dx.doi.org/10.5304/jafscd.2016.062.025

Copyright (C) 2016 by New Leaf Associates, Inc.

$\mathrm{T}$ oby Hemenway's recent book is a well grounded follow-up to his earlier book, Gaia's Garden, which was instrumental in introducing the concept of permaculture to an American audience. Despite the fact that many books on permaculture have been published since its 2001 publication, Hemenway's earlier publication remains the best-selling permaculture book in the U.S.

a * Corresponding author: Sharon Ferguson, Senior Planner, Anchorage, Alaska, and permaculturist; strawdesign@gmail.com

b Jillian Ferguson, Community Development Planner, Chicopee, Massachusetts; radicledesign@gmail.com
It is not necessary to have a familiarity with permaculture prior to reading The Permaculture City, as the author has done a masterful job of explaining permaculture principles, design methods, and the steps of the design process. Permaculture is described as "a set of decision-making tools, based on natural systems, for arriving at regenerative solutions to design challenges of all kinds" (p. xii). Permaculture is concerned with the design of ecological human habitats and food production systems. It is a land-use and community-building design method that strives for the harmonious integration of human dwellings, microclimate, annual and perennial plants, animals, soils, and 
water into stable, productive communities. The focus is not on these elements themselves, but rather on the symbiotic relationships created among them by the way we place them in the landscape. This synergy is enhanced by mimicking patterns found in nature.

Those interested in ecological design, agriculture and food systems, as well as city planners, landscape architects, civil engineers, and developers should read The Permaculture City. Permaculture, as the author notes, is a universal design tool that has something to offer everyone. As permaculture applies whole-systems thinking to problem solving, it offers a clear approach for the development of regenerative human settlements. The author states: "Permaculture is not a discipline in itself or a set of techniques but rather a design approach that connects different disciplines and makes use of a wealth of strategies and techniques. It, like nature, uses and combines the best features of whatever is available to it" (p. xii). Hemenway brings forth the notion that we need a new academic discipline that tethers the disciplines involved in the design and building of communities, resulting in an integrated practice that achieves a resilient way of living on a finite planet.

More than 50 percent of the world's population now lives in urban areas. As the population shifts to high density communities, urbanists must develop new resilient practices considering the depletion of oil supplies, dwindling water resources, and climate change. Hemenway offers a positive path forward through in-depth exploration of design for the urban home and community, specifically gardens, water, and energy solutions. Hemenway encourages community empowerment by securing the livelihoods of community members through engaging and deliberate design. The valid and sensible examples of permaculture practices demonstrate that designers and planners are now in a position to begin to scale these practices up to advance more regenerative communities.

Throughout Hemenway's book, various leverage points-points of intervention where the least work accomplishes the most change-are identified. For example, there are several leverage points that influence microclimates in town yards. Microclimates are shaped by the sun, breezes, and moisture interacting with buildings, slopes, plantings, road surfaces, and other physical elements. Through thoughtful placement of these elements, designers can extend the growing season, stretch the plant palette into less hardy species, reduce heating and cooling costs, and provide comfortable year-round yard space that is neither too hot nor too cold.

Hemenway explores household water-saving projects before analyzing ways to store water in the soil. The author addresses greywater techniques as well as several methods of capturing and using rainwater. The author makes note of several irrigation methods that are inexpensive, reduce water use, and use appropriate greywater strategies such as proper location and complimentary vegetation.

The ability to transport people and goods is important in a well-functioning city. While the author notes the need to establish resilient processes for the provision of water, food, and energy, he overlooks the vital role of transportation. In a low-carbon future, the book would be strengthened with resilient solutions to transportation, whether through the construction of more bicycle facilities or recognition of the growing role that cargo bikes are playing in moving goods through city streets.

The book is well organized and eye-catching, with sidebars, full-page panels with examples, and explanations of permaculture techniques and principles in a distinctive gray color, providing an illustrative and engaging experience. A three-page panel is devoted to methods of enhancing microclimates in town yards.

The Permaculture City offers hopeful and inspiring case studies of projects in metropolitan areas around the country. It is of tremendous value to anyone concerned with our uncertain future and the need to build communities positioned to meet future demands for dynamic and resilient urban living. 